\title{
PENINGKATAN PRODUKTIVITAS MELALUI UPAYA ENVIROMENTAL RISK ANALYSIS UNTUK MENDUKUNG PELAKSANAAN GREEN PRODUCTIVITY
}

\author{
${ }^{1}$ Agus supriyadi, ${ }^{2}$ Athika Sidhi Cahyana \\ ${ }^{1,2}$ Program Studi Teknik Industri, Fakultas Teknik Universitas Muhammadiyah Sidoarjo \\ Kampus 2: Jl. Raya Gelam 250 Candi Sidoarjo \\ e-mail: supriyadiagust.42@gmail.com
}

\begin{abstract}
$P G X Y Z$ as one of the sugar industries that have the potential for waste pollution needs to make improvements both in the production process and in the management of its environment. With various existing waste conditions such as in industrial wastewater. Therefore, a systematic application is needed to minimize the possibility of environmental risks. so that identification, assessment and analysis of environmental risk based on the concept of environmental risk management using qualitative methods, semi-quantitative methods and the significance of aspects. followed by EPI calculation to support the implementation of green productivity. the objectives of this study are to identify and analyze environmental risks in the sugar processing industry wastewater based on the concept of environmental risk management. Evaluate the factors that influence the productivity of environmental performance to support the implementation of green productivity. The result of this study is that installation of wastewater treatment has a low risk with a total risk value of 77 which means that management is carried out by routine procedures. Whereas the results of the environmental risk assessment of production activities which have the most environmental impact are turbine oil lubrication at the boiler station with a score of 1701, at the "blotong" process purification station with a score of 729. Factors that influence environmental performance productivity are the performance of the boiler station and oil from the turbine steam that is carried into liquid waste. EPI index measurement results have a positive value of $35.24 \%$, this indicates that the environmental performance of the sugar mills studied is good enough
\end{abstract}

Key words : Environmental Risk Analysis; EPI; Green Productivity

\begin{abstract}
Abstrak
PG XYZ sebagai salah satu industri gula yang memiliki potensi pencemaran limbah perlu melakukan perbaikan baik dalam proses produksi maupun pada pengelolaan lingkungannya. Berbagai kondisi limbah yang ada seperti pada air limbah industri. Aplikasi sistematis dibutuhkan untuk mememinimasi kemungkinan terjadinya resiko terhadap lingkungan. sehingga dilakukan identifikasi, penilaian dan analisis resiko lingkungan berdasarkan konsep manajemen resiko lingkungan dengan menggunakan metode kualitatif, metode semi kuantitatif dan signifikansi aspek. dilanjutkan dengan perhitungan EPI untuk mendukung pelaksanaan green productivity. tujuan dari penelitian ini adalah yaitu mengidentifikasi dan analisis resiko lingkungan pada air limbah industri pengolahan gula berdasarkan konsep manajemen resiko lingkungan. Selanjutnya melakukan evaluasi faktor-faktor yang berpengaruh terhadap produktivitas kinerja lingkungan untuk mendukung pelaksanaan green productivity. hasil dari penelitian ini adalah intalasi pengolahan air limbah memiliki resiko rendah dengan total nilai resiko 77 artinya pengelolaan dilakukan dengan prosedur rutin. Hasil penilaian resiko lingkungan kegiatan produksi yang paling banyak menimbulkan dampak lingkungan adalah proses minyak pelumasan turbin pada stasiun ketel dengan skor 1701, pada stasiun pemurnian proses blotong dengan skor 729. Faktor faktor yang mempengaruhi produktivitas kinerja lingkungan yaitu kinerja dari stasiun ketel dan minyak dari turbin uap yang terbawa ke limbah cair. hasil pengukuran indeks EPI memiliki nilai positif 35,24\% hal ini menunjukkan bahwa kinerja lingkungan pabrik gula yang diteliti sudah cukup baik.
\end{abstract}

Kata kunci : Environmental Risk Analysis; EPI; Green Productivity

\section{PENDAHULUAN}

PG XYZ sebagai salah satu industri gula di Indonesia yang memiliki potensi pencemaran limbah perlu melakukan perbaikan baik dalam proses produksi maupun pada pengelolaan lingkungannya terutama dalam pengelolaan limbah yang dihasilkan dari proses produksinya. Berbagai kondisi limbah yang ada seperti pada air limbah industri dan sebagainya. maka berbagai dampak negatif yang kemungkinan akan muncul dan berpotensi menimbulkan resiko, antara lain: 
1. Perubahan tata guna lahan

2. Pencemaran udara

3. Pencemaran air tanah

4. Pencemaran air permukaan

5. Penurunan jumlah flora darat

6. Penurunan jumlah flora air

7. Penurunan jumlah fauna darat

8. Penurunan jumlah fauna air

9. Penurunan tingkat kesehatan masyarakat

10. Berkurangnya estetika lingkungan

Dari beberapa dampak negatif yang kemungkinan akan terjadi. diperlukan suatu penilaian terhadap resiko lingkungan dan dalam kegiatan penelitian ini akan dilakukan penilaian resiko meliputi: peluang terjadinya dampak, besaran dampak, frekuensi kejadian, luasan dampak, keseriusan resiko, peluang terjadinya resiko dan waktu pemaparan untuk mendukung pelaksanaan green productivity sehingga digunakan metode enviromental risk analysis yaitu kegiatan memperkirakan munculnya suatu resiko dari suatu kegiatan dan menentukan dampak dari kegiatan atau peristiwa tersebut dalam analisis ini digunakan tiga metode yaitu analysis of qualitative, semi quantitative and enviromental analysis significantly. 


\section{METODE PENELITIAN}

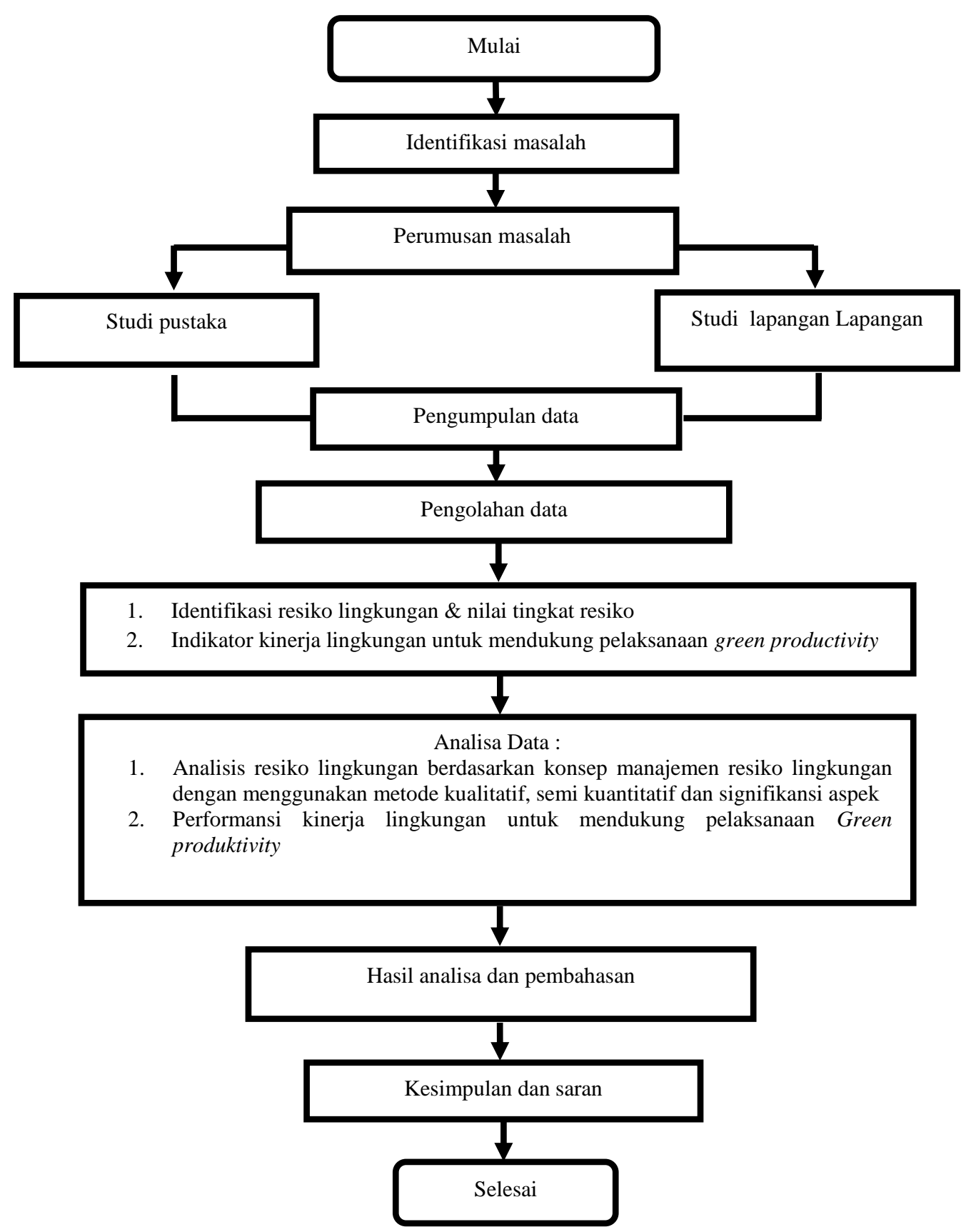

Gambar 1. Diagram alir penelitian

\section{A. Tahap Awal Penelitian}

Tahap awal penelitian merupakan tahap pengumpulan informasi untuk proses identifikasi masalah, merumuskan masalah, dan menentukan tujuan dari proses pemecahan masalah dengan mempertimbangkan ilmu pengetahuan dan studi literatur.:

\section{B. Identifikasi Masalah}

Survei awal dilakukan untuk mengetahui dan mengindentifikasi kondisi serta permasalahan aktual yang terjadi pada saat kegiatan proses produksi berlangsung di PG XYZ 


\section{Perumusan Masalah}

Dalam perumusan masalah menjelaskan pertanyaan mengenai permasalahan yang ingin diselesaikan terhadap objek yang diteliti sehingga tepat sasaran pada pokok permasalahan.

\section{Studi Pustaka}

Studi pustaka dilakukan untuk mengetahui penjelasan secara teoritis baik secara umum maupun secara khusus mengenai metode-metode yang akan digunakan dalam penelitian untuk menyelesaikan permasalahan yang sedang terjadi. Teori-teori tersebut didapat dari beberapa literatur berupa buku, artikel, dan jurnal penelitian.

\section{E. Penetapan Tujuan Penelitian}

Penetapan tujuan penelitian ini dilakukan supaya penelitian yang dikerjakan sesuai dengan sasaran yang ingin dicapai oleh penulis, serta tujuan tersebut digunakan sebagai acuan dalam melakukan penelitian.

\section{F. Tahap Pengumpulan Data}

Dalam tahap pengumpulan data, kumpulan data yang telah didapat dibagi menjadi dua sumber data, yaitu Pengumpulan data primer adalah pengumpulan data secara langsung dari pihak-pihak yang terkait dengan pokok pembahasan yang sedang diteliti di perusahaan tempat penelitian.Pengumpulan data sekunder adalah pengumpulan data secara langsung dengan melihat permasalahan yang ada. Pengumpulan data yang digunakan oleh penulis adalah metode kepustakaan. Metode ini dilakukan oleh penulis dengan cara mempelajari literatur yang bersumber dari artikel, jurnal ilmiah, dan buku yang mana literatur tersebut berkaitan dengan materi yang diambil untuk mendukung landasan teori dalam penelitian yang dilakukan di perusahaan.

\section{G. Tahap Pengolahan Data}

Tahap pengolahan data dilakukan dengan melakukan (assessment) penilaian resiko lingkungan menggunakan metode kaualitatif dan semi kuantitatif dan aspek signifikan di lanjutkan performansi kinerja lingkungan untuk mendukung penerapan green productivity.

\section{H. Tahap Analisa Hasil}

Pada tahap ini akan menjelaskan mengenai tahapan-tahapan analisa yang dilakukan dalam penelitian serta melakukan pembahasan terhadap permasalahan yang sedang diteliti. Analisa dan pembahasan, pada tahap ini dari hasil pengolahan data kemudian di analisis resiko lingkungan dilakukan dengan membandingkan kondisi yang ada dengan parameter lingkungan sehingga dapat diketahui tingkat resikonya.

\section{Tahap Kesimpulan dan Saran}

Pada tahap ini akan menjelaskan mengenai tahapan-tahapan analisa yang dilakukan dalam penelitian serta melakukan pembahasan terhadap permasalahan yang sedang diteliti dengan menganalisa penilaian resiko lingkungan untuk mendukung pelaksanaan green productivity dan menentukan alternatif solusi perbaikan.

\section{HASIL DAN PEMBAHASAN}

\section{A. Analisis Metode Kualitatif}

Analisis resiko dengan metode kualitatif dilakukan dengan mengkombinasikan antara nilai peluang terjadinya resiko dan besarnya resiko sehingga akan dihasilkan nilai resiko yang terdiri dari resiko tinggi, resiko menengah, resiko berarti, dan resiko rendah. (Kasam., 2011). 
Tabel 5. Matriks nilai resiko kualitatif

\begin{tabular}{|c|c|c|c|}
\hline Resiko & Peluang Resiko & $\begin{array}{c}\text { Level } \\
\text { Besaran }\end{array}$ & Nilai Resiko \\
\hline Tata guna lahan (tanah) & $\mathrm{E}$ & 2 & $\mathrm{~L}$ \\
\hline Pencemaran udara & $\mathrm{D}$ & 2 & $\mathrm{~L}$ \\
\hline Pencemaran air tanah & $\mathrm{C}$ & 3 & $\mathrm{M}$ \\
\hline Pencemaran air Permukaan & $\mathrm{C}$ & 3 & M \\
\hline $\begin{array}{l}\text { Penurunan jumlah flora } \\
\text { darat }\end{array}$ & $\mathrm{D}$ & 2 & $\mathrm{~L}$ \\
\hline Penurunan jumlah flora air & $\mathrm{C}$ & 3 & M \\
\hline $\begin{array}{l}\text { Penurunan jumlah fauna } \\
\text { darat }\end{array}$ & $\mathrm{D}$ & 2 & $\mathrm{~L}$ \\
\hline $\begin{array}{l}\text { Penurunan jumlah fauna } \\
\text { air }\end{array}$ & $\mathrm{C}$ & 3 & M \\
\hline $\begin{array}{l}\text { Penurunan tingkat } \\
\text { kesehatan masyarakat }\end{array}$ & $\mathrm{C}$ & 3 & $\mathrm{M}$ \\
\hline $\begin{array}{l}\text { Berkurangnya estetika } \\
\text { lingkungan }\end{array}$ & $\mathrm{D}$ & 2 & $\mathrm{~L}$ \\
\hline
\end{tabular}

Keterangan:
A: Hampir pasti terjadi
H: Resiko Tinggi
B: Kemungkinan besar
M: Resiko menengah
C: Kemungkinan sedang
S: Resiko berarti
D; Kemungkinan kecil
L: Resiko rendah
E: Jarang
1: Pengaruh tidak berarti
2: Pengaruh kecil
3: Pengaruh sedang
4: Pengaruh besar
5: Pengaruh sangat besar

\section{B. Analisis Semi Kuantitatif}

Analisis semi kuantitatif yang menggabungkan antara unsur frekuensi kejadian, besaran kejadian dan sensitifitas seperti terlihat pada Tabel 6.

Tabel 6. Nilai resiko semi kuantitatif

\begin{tabular}{lcccc}
\hline \multicolumn{1}{c}{ Resiko } & $\begin{array}{c}\text { Frekuensi } \\
(\mathbf{F})\end{array}$ & $\begin{array}{c}\text { Pengaruh } \\
(\mathbf{S 1})\end{array}$ & $\begin{array}{c}\text { Sensitivitas } \\
(\mathbf{S 2})\end{array}$ & $\begin{array}{c}\text { Nilai Resiko } \\
\text { R=Fx(S1+S2) }\end{array}$ \\
\hline Tata guna lahan (tanah) & 1 & 3 & 2 & 5 \\
Pencemaran udara & 2 & 2 & 2 & 8 \\
Pencemaran air tanah & 2 & 2 & 2 & 8 \\
Pencemaran air Permukaan & 3 & 2 & 2 & 12 \\
Penurunan jumlah flora darat & 2 & 2 & 2 & 8 \\
Penurunan jumlah flora air & 2 & 2 & 1 & 6 \\
Penurunan jumlah fauna darat & 2 & 2 & 2 & 8 \\
Penurunan jumlah fauna air & 2 & 2 & 2 & 8 \\
Penurunan tingkat kesehatan & 2 & 2 & 2 & 6 \\
masyarakat & 2 & 2 & 1 & 77 \\
Berkurangnya estetika & & & & \\
lingkungan & & & & \\
Total Resiko & & &
\end{tabular}

Keterangan : Nilai resiko

(0) $-(150)=$ resiko rendah pengelolaan dengan prosedur yang rutin 
(151) $-(300)=$ resiko sedang, memerlukan perhatian manajemen tingkat tinggi.

(301 ) $-(450)=$ resiko tinggi memerlukan penelitian dan manajemen terperinci

Adapun secara keseluruhan total nilai resikonya adalah rendah dengan nilai 77 artinya pengelolaan dilakukan dengan prosedur rutin.

Tabel sinifikansi aspek yang terdiri dari luasan dampak, keseriusan dampak keboleh jadian dampak, waktu pemaparan peraturan perundangan dan metode pengendalian serta image perusahaan.

Tabel 7. Signifikansi aspek lingkungan outlet IPAL

\begin{tabular}{|c|c|c|c|c|c|c|c|c|}
\hline \multirow[t]{2}{*}{ Komponen lingkungan } & \multicolumn{7}{|c|}{$\begin{array}{c}\text { Nilai } \\
\text { Kondisi Normal }\end{array}$} & \multirow{2}{*}{$\begin{array}{c}\text { Resiko } \\
\left(\mathrm{LD}^{*} \mathrm{KD} \mathrm{F}^{*} \mathrm{~F} \mathrm{~F}\right. \\
\mathrm{P}^{*} \mathrm{WP} \mathrm{MP}^{*} \mathrm{I} \\
\mathrm{M})\end{array}$} \\
\hline & LD & $\mathrm{KD}$ & $\mathrm{F}$ & PP & WP & MP & IM & \\
\hline Perubahan tata guna lahan & 3 & 3 & 1 & 3 & 3 & 1 & 1 & 81 \\
\hline Pencemaran udara & 1 & 3 & 1 & 3 & 3 & 1 & 1 & 27 \\
\hline Pencemaran air tanah & 3 & 3 & 3 & 3 & 3 & 1 & 1 & 243 \\
\hline $\begin{array}{l}\text { Pencemaran air } \\
\text { permukaan }\end{array}$ & 3 & 3 & 3 & 3 & 3 & 1 & 1 & 243 \\
\hline $\begin{array}{l}\text { Penurunan jumlah flora } \\
\text { darat (terestrial) }\end{array}$ & 1 & 3 & 3 & 3 & 3 & 1 & 1 & 81 \\
\hline $\begin{array}{l}\text { Penurunan jumlah flora } \\
\text { air (aquatik) }\end{array}$ & 1 & 3 & 3 & 3 & 3 & 1 & 1 & 81 \\
\hline $\begin{array}{l}\text { Penurunan jumlah fauna } \\
\text { darat } \\
\text { Penurunan jumlah fauna }\end{array}$ & 1 & 3 & 3 & 3 & 3 & 1 & 1 & 81 \\
\hline $\begin{array}{l}\text { air } \\
\text { Penurunan tingkat }\end{array}$ & 1 & 3 & 3 & 3 & 3 & 1 & 1 & 81 \\
\hline $\begin{array}{l}\text { kesehatan masyarakat } \\
\text { Berkurangnya estetika }\end{array}$ & 3 & 3 & 3 & 3 & 3 & 1 & 1 & 243 \\
\hline $\begin{array}{l}\text { lingkungan } \\
\text { Total ni }\end{array}$ & $\begin{array}{l}3 \\
\text { i anal }\end{array}$ & $\begin{array}{l}3 \\
\text { is sign }\end{array}$ & $\begin{array}{c}3 \\
\text { fika }\end{array}$ & $\begin{array}{c}3 \\
\text { i asp }\end{array}$ & 3 & 1 & 1 & $\begin{array}{c}243 \\
1404\end{array}$ \\
\hline
\end{tabular}

Keterangan :

LD: luasan dampak

KD: Keseriusan Dampak

F: keboleh jadian dampak

PP: Peraturan perundangan

WP: waktu pemaparan

MP: Metode pengendalian

IM: image Perusahaan terhadap masyarakat

Menurut kriteria aspek lingkungan tidak signifikan bila hasil evaluasi menunjukkan nilai 1 196.000, cukup signifikan bila 196.001- 392.000 dan signifikan bila 392.001- 588.245 (Razif., 2002) dalam (Basuki, 2015)

Ternyata dari hasil evaluasi tidak ada aspek lingkungan signifikan karena angka semuanya berada di bawah 196.000 yaitu sebesar 1404 artinya dampak yang ditimbulkan tidak ada pengaruh yang kuat dan berbahaya terhadap komponen lingkungan. 
Tabel 8. Penilaian resiko lingkungan kegiatan produksi

Unit kerja ; proses pembuatan gula

Aktivitas : gilingan,pemurnian, penguapan, kristalisasi, puteran, ketel, laboratorium dan bengkel mekanik

\begin{tabular}{|c|c|c|c|c|c|c|c|c|c|c|}
\hline \multirow{2}{*}{$\begin{array}{c}\text { Kegiatan / } \\
\text { Produk }\end{array}$} & \multirow{2}{*}{$\begin{array}{c}\text { Aspek } \\
\text { lingkungan }\end{array}$} & \multirow{2}{*}{$\begin{array}{c}\text { Dampak } \\
\text { Lingkungan } \\
\end{array}$} & \multicolumn{8}{|c|}{ Kondisi Normal } \\
\hline & & & LD & KD & $\mathbf{F}$ & PP & WP & MP & IM & SKOR \\
\hline \multirow[t]{7}{*}{ Penggilingan } & Minyak oli & $\begin{array}{l}\text { pencemaran } \\
\text { air }\end{array}$ & 3 & 3 & 3 & 3 & 3 & 1 & 1 & 243 \\
\hline & $\begin{array}{l}\text { tebu } \\
\text { tellin }\end{array}$ & air & 1 & 3 & 3 & 3 & 3 & 1 & 1 & 81 \\
\hline & $\begin{array}{l}\text { Air } \\
\text { pendingin }\end{array}$ & $\begin{array}{l}\text { pencemaran } \\
\text { air }\end{array}$ & 1 & 3 & 3 & 3 & 3 & 1 & 1 & 81 \\
\hline & $\begin{array}{l}\text { bukan tebu } \\
\text { akar, pasir }\end{array}$ & $\begin{array}{l}\text { lingkungan } \\
\text { kotor } \\
\text { pencemaran }\end{array}$ & 1 & 1 & 3 & 3 & 3 & 1 & 1 & 27 \\
\hline & Daduk tebu & $\begin{array}{l}\text { udara } \\
\text { lingkungan }\end{array}$ & 1 & 1 & 3 & 3 & 3 & 1 & 1 & 27 \\
\hline & Ampas & kotor & 1 & 3 & 3 & 3 & 3 & 1 & 1 & 81 \\
\hline & $\begin{array}{l}\text { pencucian } \\
\text { tebu } \\
\text { Sisa }\end{array}$ & $\begin{array}{l}\text { kontaminasi } \\
\text { tanah }\end{array}$ & 3 & 3 & 3 & 3 & 3 & 1 & 1 & 243 \\
\hline \multirow[t]{4}{*}{$\begin{array}{l}\text { Stasiun } \\
\text { pemurnian }\end{array}$} & $\begin{array}{l}\text { pendingin } \\
\text { vakum } \\
\text { Pendingin }\end{array}$ & $\begin{array}{l}\text { pencemaran } \\
\text { air } \\
\text { pencemaran }\end{array}$ & 3 & 3 & 3 & 3 & 3 & 1 & 1 & 243 \\
\hline & sublimator & $\begin{array}{l}\text { air } \\
\text { pencemaran }\end{array}$ & 1 & 3 & 3 & 3 & 3 & 1 & 1 & 81 \\
\hline & $\mathrm{SO} 2$ & udara & 3 & 3 & 3 & 3 & 3 & 1 & 1 & 243 \\
\hline & $\begin{array}{l}\text { Blotong dan } \\
\text { bau }\end{array}$ & $\begin{array}{l}\text { pencemaran } \\
\text { udara } \\
\text { nencemaran }\end{array}$ & 3 & 3 & 3 & 3 & 3 & 3 & 1 & 729 \\
\hline \multirow[t]{3}{*}{$\begin{array}{l}\text { Stasiun } \\
\text { penguapan }\end{array}$} & $\begin{array}{l}\text { Soda } \\
\text { Pendingin }\end{array}$ & $\begin{array}{l}\text { air } \\
\text { pencemaran }\end{array}$ & 1 & 3 & 3 & 3 & 3 & 1 & 1 & 81 \\
\hline & kondensor & air & 1 & 3 & 3 & 3 & 3 & 1 & 1 & 81 \\
\hline & $\begin{array}{l}\text { Hasil skrap } \\
\text { Pendingin }\end{array}$ & $\begin{array}{l}\text { limbah padat } \\
\text { pencemaran }\end{array}$ & 1 & 3 & 3 & 3 & 3 & 1 & 1 & 81 \\
\hline $\begin{array}{l}\text { kristalisasi } \\
\text { Stasiun }\end{array}$ & kondensor & $\begin{array}{l}\text { air } \\
\text { pencemaran }\end{array}$ & 1 & 3 & 3 & 3 & 3 & 1 & 1 & 81 \\
\hline puteran & $\begin{array}{l}\text { Tetes } \\
\text { Sisa air }\end{array}$ & $\begin{array}{l}\text { air } \\
\text { pencemaran }\end{array}$ & 1 & 3 & 3 & 3 & 3 & 1 & 1 & 81 \\
\hline \multirow[t]{3}{*}{ ketel } & $\begin{array}{l}\text { kurasan } \\
\text { Sisa minyak }\end{array}$ & air & 1 & 3 & 3 & 3 & 3 & 1 & 1 & 81 \\
\hline & $\begin{array}{l}\text { pelumasan } \\
\text { turbin } \\
\text { Abu dalam }\end{array}$ & $\begin{array}{l}\text { pencemaran } \\
\text { air } \\
\text { kontaminasi }\end{array}$ & 3 & 3 & 3 & 3 & 3 & 7 & 1 & 1701 \\
\hline & $\begin{array}{l}\text { air } \\
\text { Sisa bahan }\end{array}$ & $\begin{array}{l}\text { tanah } \\
\text { pencemaran }\end{array}$ & 1 & 3 & 3 & 3 & 3 & 1 & 1 & 81 \\
\hline Laboratorium & $\begin{array}{l}\text { kimia } \\
\text { Sisa bekas }\end{array}$ & air & 1 & 3 & 3 & 3 & 3 & 1 & 1 & 81 \\
\hline \multirow{3}{*}{$\begin{array}{l}\text { Bengkel } \\
\text { mekanik }\end{array}$} & $\begin{array}{l}\text { kertas saring } \\
\text { sisa ceceran }\end{array}$ & $\begin{array}{l}\text { limbah padat } \\
\text { kontaminasi }\end{array}$ & 1 & 1 & 3 & 3 & 3 & 1 & 1 & 27 \\
\hline & $\begin{array}{l}\text { oli } \\
\text { percikan api }\end{array}$ & $\begin{array}{l}\text { tanah } \\
\text { keselamatan }\end{array}$ & 1 & 1 & 3 & 3 & 3 & 1 & 1 & 27 \\
\hline & & kerja & 1 & 1 & 1 & 1 & 1 & 1 & 1 & 1 \\
\hline
\end{tabular}


Dari hasil penilaian resiko lingkungan kegiatan produksi diketahui bahwa tahapan yang paling banyak menimbulkan dampak lingkungan adalah stasiun ketel pada tahapan proses pelumasan turbin dengan skor 1701 .

Tabel 9. Penilaian aspek lingkungan penting

Unit Kerja ; proses pembuatan gula

Aktivitas : gilingan, pemurnian, penguapan, kristalisasi, puteran, ketel, laboratorium dan bengkel mekanik

\begin{tabular}{|c|c|c|c|c|c|c|c|c|c|c|}
\hline \multirow{2}{*}{$\begin{array}{c}\text { Kegiatan / } \\
\text { Produk / } \\
\text { Jasa }\end{array}$} & \multirow{2}{*}{$\begin{array}{c}\text { Aspek } \\
\text { lingkungan }\end{array}$} & \multirow[t]{2}{*}{ Uraian } & \multirow{2}{*}{$\begin{array}{c}\text { Dampak } \\
\text { lingkungan }\end{array}$} & \multicolumn{7}{|c|}{$\begin{array}{c}\text { Kriteria Aspek Penting } \\
\text { Jum- }\end{array}$} \\
\hline & & & & 1 & 2 & 3 & 4 & 5 & lah & Ket \\
\hline \multirow[t]{8}{*}{ Penggilingan } & Minyak oli & $\begin{array}{l}\text { Pembuangan } \\
\text { limbah }\end{array}$ & $\begin{array}{l}\text { pencemaran } \\
\text { air }\end{array}$ & 10 & 5 & 1 & 1 & 10 & 27 & penting \\
\hline & $\begin{array}{l}\text { Penggilingan } \\
\text { tebu }\end{array}$ & $\begin{array}{l}\text { Pembuangan } \\
\text { limbah } \\
\text { Pembuangan }\end{array}$ & $\begin{array}{l}\text { pencemaran } \\
\text { air } \\
\text { pencemaran }\end{array}$ & 5 & 10 & 1 & 1 & 5 & 22 & penting \\
\hline & Air pendingin & limbah & air & 5 & 10 & 1 & 1 & 5 & 22 & penting \\
\hline & Kotoran bukan & Pembuangan & lingkungan & & & & & & & \\
\hline & tebu akar ,pasir & $\begin{array}{l}\text { limbah } \\
\text { Pembuangan }\end{array}$ & $\begin{array}{l}\text { kotor } \\
\text { pencemaran }\end{array}$ & 5 & 10 & 1 & 1 & 5 & 22 & penting \\
\hline & Daduk tebu & $\begin{array}{l}\text { limbah } \\
\text { Pembuangan }\end{array}$ & $\begin{array}{l}\text { udara } \\
\text { lingkungan }\end{array}$ & 5 & 10 & 1 & 1 & 5 & 22 & penting \\
\hline & Ampas & $\begin{array}{l}\text { limbah } \\
\text { Pembuangan }\end{array}$ & $\begin{array}{l}\text { kotor } \\
\text { pencemaran }\end{array}$ & 5 & 10 & 1 & 1 & 5 & 22 & penting \\
\hline & $\begin{array}{l}\text { Sisa pencucian } \\
\text { tebu }\end{array}$ & limbah & air & 5 & 10 & 1 & 1 & 5 & 22 & penting \\
\hline \multirow[t]{4}{*}{$\begin{array}{l}\text { Stasiun } \\
\text { pemurnian }\end{array}$} & $\begin{array}{l}\text { Sisa pendingin } \\
\text { vakum }\end{array}$ & $\begin{array}{l}\text { Pembuangan } \\
\text { limbah }\end{array}$ & $\begin{array}{l}\text { pencemaran } \\
\text { air }\end{array}$ & 5 & 10 & 1 & 1 & 5 & 22 & penting \\
\hline & $\begin{array}{l}\text { Pendingin } \\
\text { sublimator } \\
\text { SO2 }\end{array}$ & $\begin{array}{l}\text { Pembuangan } \\
\text { limbah } \\
\text { Polusi udara }\end{array}$ & $\begin{array}{l}\text { pencemaran } \\
\text { air } \\
\text { pencemaran }\end{array}$ & 5 & 10 & 1 & 1 & 5 & 22 & penting \\
\hline & & & udara & 5 & 10 & 1 & 1 & 5 & 22 & penting \\
\hline & $\begin{array}{l}\text { Blotong dan } \\
\text { bau }\end{array}$ & $\begin{array}{l}\text { pembuangan } \\
\text { limbah }\end{array}$ & $\begin{array}{l}\text { pencemaran } \\
\text { udara }\end{array}$ & 10 & 10 & 1 & 1 & 5 & 27 & penting \\
\hline \multirow[t]{5}{*}{$\begin{array}{l}\text { Stasiun } \\
\text { penguapan }\end{array}$} & Soda & $\begin{array}{l}\text { Pembuangan } \\
\text { limbah }\end{array}$ & $\begin{array}{l}\text { pencemaran } \\
\text { air }\end{array}$ & 5 & 10 & 1 & 1 & 5 & 22 & penting \\
\hline & Pendingin & Pembuangan & pencemaran & & & & & & & \\
\hline & kondensor & limbah & air & 5 & 10 & 1 & 1 & 5 & 22 & penting \\
\hline & Hasil skrap & Pembuangan & limbah padat & & & & & & & \\
\hline & & limbah & & 5 & 10 & 1 & 1 & 5 & 22 & penting \\
\hline \multirow{4}{*}{$\begin{array}{l}\text { Masakan } \\
\text { kristalisasi } \\
\text { Stasiun } \\
\text { puteran }\end{array}$} & Pendingin & Pembuangan & pencemaran & & & & & & & \\
\hline & kondensor & limbah & air & 5 & 10 & 1 & 1 & 5 & 22 & penting \\
\hline & & Pembuangan & pencemaran & & & & & & & \\
\hline & Tetes & $\begin{array}{l}\text { limbah } \\
\text { Pembuangan }\end{array}$ & $\begin{array}{l}\text { air } \\
\text { pencemaran }\end{array}$ & 10 & 10 & 1 & 1 & 5 & 27 & penting \\
\hline \multirow[t]{3}{*}{ ketel } & Sisa air kurasan & $\begin{array}{l}\text { limbah } \\
\text { Pembuangan }\end{array}$ & $\begin{array}{l}\text { air } \\
\text { pencemaran }\end{array}$ & 5 & 10 & 1 & 1 & 5 & 22 & penting \\
\hline & Abu dalam air & limbah & air & 5 & 10 & 1 & 1 & 5 & 22 & penting \\
\hline & Sisa bahan & Pembuangan & pencemaran & & & & & & & \\
\hline \multirow[t]{3}{*}{ Laboratorium } & kimia & limbah & air & 5 & 10 & 1 & 1 & 5 & 22 & penting \\
\hline & Sisa bekas & Pembuangan & limbah padat & & & & & & & \\
\hline & kertas saring & limbah & & 5 & 10 & 1 & 1 & 5 & 22 & penting \\
\hline \multirow{3}{*}{$\begin{array}{l}\text { Bengkel } \\
\text { mekanik }\end{array}$} & & Pembuangan & kontaminasi & & & & & & & \\
\hline & sisa ceceran oli & limbah & $\begin{array}{l}\text { tanah } \\
\text { keselamatan }\end{array}$ & 5 & 10 & 1 & 1 & 5 & 22 & penting \\
\hline & percikan api & & kerja & 5 & 10 & 1 & 1 & 5 & 22 & penting \\
\hline
\end{tabular}


Dari Tabel 9 penilaian aspek penting skor tertinggi didapat pada kegiatan penggilingan,stasiun pemurnian dan puteran Artinya kegiatan tersebut penting untuk segera dilakukan perbaikan pengelolaan dengan prosedur yang rutin.

Setelah melakukan pengumpulan data dan penyebaran kuesioner maka selanjutnya adalah melakukan penilaian terhadap kinerja lingkungan dengan menggunakan indeks EPI.

Tabel 10. Perhitungan indeks EPI

\begin{tabular}{lccccc}
\hline Variabel & $\begin{array}{c}\text { Bobot } \\
(\mathbf{W i})\end{array}$ & $\begin{array}{c}\text { Standart } \\
\text { Bapedal }\end{array}$ & $\begin{array}{c}\text { Hasil } \\
\text { Analisa }\end{array}$ & $\begin{array}{c}\text { Penyimngan } \\
(\mathbf{P i})\end{array}$ & $\begin{array}{c}\text { Indeks EPI } \\
(\mathbf{W i * P i})\end{array}$ \\
\hline Ph & 0,144 & 8 & 6,32 & 7,21 & 1,04 \\
BOD5 & 0,144 & 60 & 4,09 & 59,93 & 8,66 \\
COD & 0,156 & 100 & 12,76 & 99,87 & 15,54 \\
Tss & 0,178 & 50 & 3,6 & 49,93 & 8,88 \\
Sulfida (S) & 0,167 & 0,5 & 0,022 & 0,46 & 0,08 \\
oil & \multirow{2}{*}{$\begin{array}{c}\text { Tidak } \\
\text { terdeteksi }\end{array}$} & \multicolumn{2}{c}{5,00} & 1,06 \\
& 0,211 & 5 & \multicolumn{2}{c}{ Total } \\
\hline
\end{tabular}

Nilai bobot didapatkan dari nilai rata-rata jawaban dari kuesioner. Nilai $P i$ : merupakan prosentase penyimpangan antara standar mengenai baku mutu limbah cair dengan hasil analisa perusahaan. hasil perhitungan yang dilakukan nilai indeks EPI sebesar 35,24 hal ini menunjukkan bahwa kinerja lingkungan pabrik gula yang diteliti sudah cukup baik dan semua parameter limbah sesuai dengan baku mutu limbah cair.

\section{Identifikasi Diagram Sebab Akibat}

Diagram sebab akibat adalah suatu bentuk diagram yang digunakan untuk mencari faktor-faktor penyebab dari suatu peyimpangan. Hubungan dalam Green Productivity, diagram ini sangat bermanfaat untuk mengilustrasikan dengan jelas macam-macam penyebab yang dapat mempengaruhi limbah produksi yang dihasilkan. Di pabrik gula ini, stasiun boiler dan pengolahan limbah cair memiliki fungsi yang paling penting. Stasiun boiler memiliki fungsi sebagai penghasil steam yang digunakan untuk membangkitkan generator listrik dan untuk proses penguapan di evaporator apabila steam yang dihasilkan tidak stabil dan biaya pembakaran sangat tinggi dapat berakibat langsung berhentinya proses produksi yang tentu sangat mempengaruhi jumlah output yang akan dihasilkan sehingga produktivitas perusahaan dapat menurun. Dari pengamatan yang dilakukan diperoleh analisis diagram sebab akibat dan dapat dilihat pada gambar berikut ini:

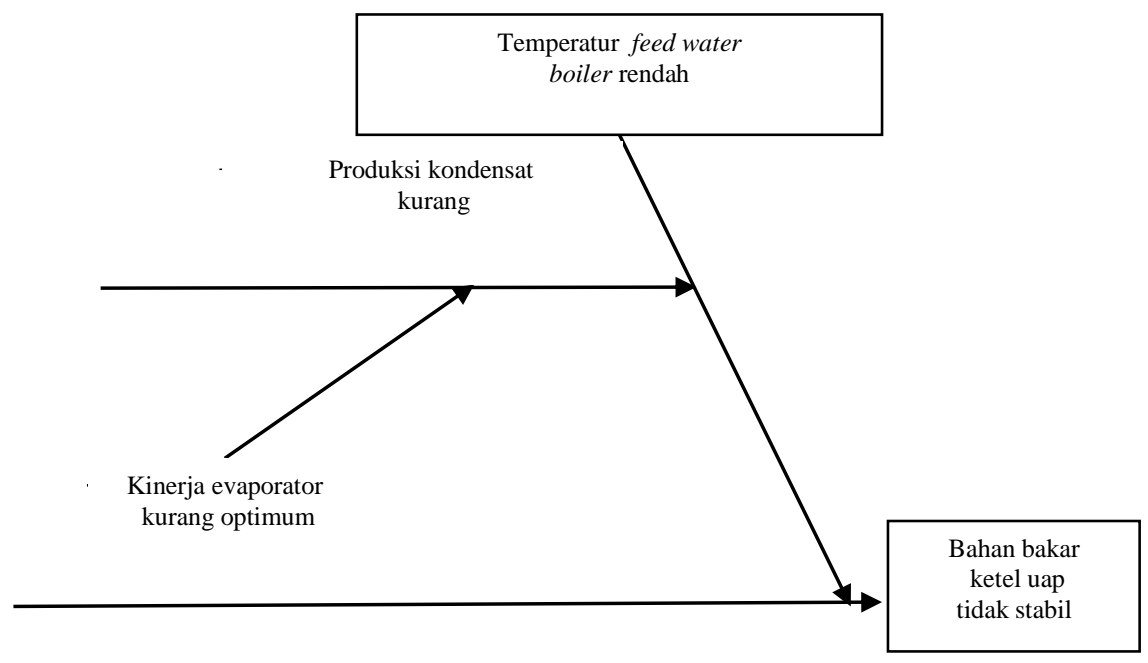

Gambar 2. Diagram sebab akibat bahan bakar pada ketel uap 


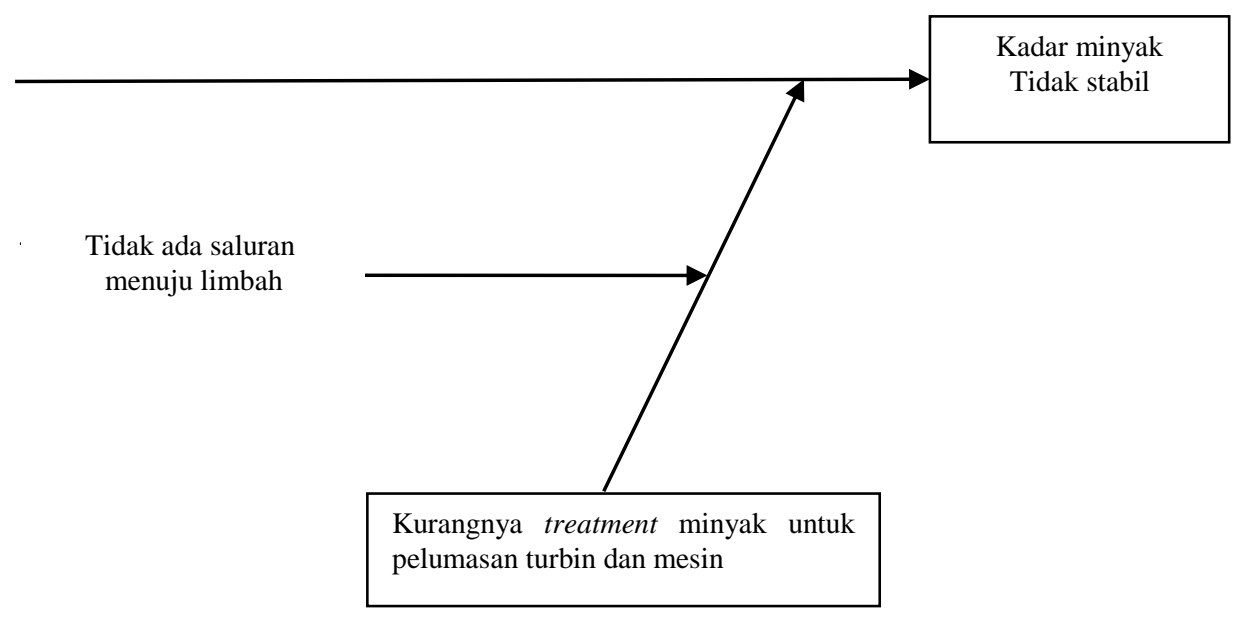

Gambar 3. Diagram sebab akibat pada limbah cair

Masalah yang mempengaruhi produktivitas dan kinerja lingkungan yaitu pada stasiun ketel yang berdampak pada limbah cair dan limbah padat blotong. tidak stabilnya temperatur di superheater dapat membuat uap kering yang di hasilkan rendah sehingga kurang mampu menggerakakan turbin-turbin. Permasalahan selanjutnya pada limbah cair adanya minyak dari proses pelumasan turbin dan mesin yang terikut di salurkan ke limbah perlu di pisahkan agar mengurangi bahaya limbah minyak dan juga menghemat kebutuhan minyak pelumas mesin. untuk mengatasi permasalahan tersebut di peroleh dua alternatif yaitu memasang bak penangkap minyak dan memasang DAF (Dissoleved Air Floatation).

\section{Penyusunan Alternatif Solusi}

Berdasarkan pada hasil analisa diagram sebab akibat di buat beberapa pilihan solusi dari kedua permasalahan untuk dapat melakukan pelaksanaan green produktivity yaitu permasalahan di ketel uap dan limbah cair.

1. Permasalahan di ketel uap

Dari permasalahan di ketel uap di peroleh dua alternatif yang dapat mengatasi permasalahan tersebut yaitu:

1) Pemasangan alat ukur panas dan penambahan bahan bakar serbuk kayu yang memiliki kalor bakar yang tinggi dari pada ampas. tujuan dari penambahan bakar serbuk kayu digunakan untuk meringankan beban bahan bakar ketel.

2) pemasangan alat ukur panas dan penambahan bahan bakar IDO sebagai bahan bakar minyak. sebagai bahan bakar tambahan di gunakan minyak bakar dengan nilai bakar yang lumayan tinggi sehingga beban bahan bakar ketel rendah dan meningkatkan air kondensat yang akan di gunakan untuk menangkap abu ketel.

2. Permasalahan limbah cair

Permasalahan selanjutnya yaitu limbah cair adanya minyak dari proses pelumasan mesin dari turbin yang terikut pada saluran limbah perlu dipisahkan secara maksimal untuk mengurangi bahaya limbah minyak dan juga penghematan kebutuhan minyak pelumas sehingga bisa terjadi penghematan biaya. Untuk mengatasi permasalahan tersebut diperoleh dua alternatif, yaitu:

1) Bak penangkap minyak, yang berguna untuk memisahkan minyak dengan air dengan perbedaan densitas (massa jenis) yaitu minyak berada di atas dan air berada di bawah. Di kolam penangkap minyak, minyak yang berada di bagian atas bak tersebut akan mengalir secara overflow. Setelah itu disalurkan kembali ke tempat penampungan minyak gelincir, sehingga kebutuhan minyak gelincir bisa terhematkan. 
2) Memasang DAF (Dissoveled Air Floatation). DAF yaitu seperangkat alat pemisah minyak dari air pada alat DAF dilengkapi tangki retensi yang berguna mengontakkan udara yang bertekanan untuk mengapungkan minyak didalam limbah yang kemudian ditangkap dengan scraper sehingga minyak akan dialirkan melalui saluran yang sudah dibuat untuk digunakan ulang dan cairannya akan dialirkan ke proses berikutnya di Unit Pengolahan Limbah Cair.

\section{SIMPULAN}

Intalasi pengelolaan air limbah memiliki resiko rendah dengan total nilai resiko 77 artinya pengelolaan dilakukan dengan prosedur rutin. komponen yang paling berpengaruh adalah limbah cair dan Ternyata dari hasil evaluasi tidak ada aspek lingkungan yang signifikan. Dari hasil penilaian resiko lingkungan kegiatan produksi yang paling banyak menimbulkan dampak lingkungan adalah proses minyak pelumasan turbin pada stasiun ketel dengan skor 1701, pada stasiun pemurnian proses blotong dengan skor 729. Faktor faktor yang mempengaruhi produktivitas kinerja lingkungan yaitu kinerja dari stasiun ketel dan minyak dari turbin uap yang terbawa ke limbah cair. Hasil pengukuran indeks EPI memiliki nilai positif 35,24\% hal ini menunjukkan bahwa kinerja lingkungan pabrik gula yang diteliti sudah cukup baik. Penanganan limbah yang ada perlu terus ditingkatkan kemampuannya. serta perlu adanya pengawasan yang terus menerus terhadap buangan limbah. Pelaksanaan green produktivity dengan hasil yang lebih akurat dan tingkat resiko yang representatif perlu diadakan studi yang lebih komprehensif utamanya dalam proses identifikasi yang lebih lengkap. menurunkan kandungan zat kimia dalam limbah agar lebih ramah lingkungan dan meningkatkan produktivitas sebaiknya dilakukan pada tahapan perbaikan proses.

\section{DAFTAR PUSTAKA}

Basuki, Kris Tri., (2015). Enviromental Risk Analysis Of Sugar Factory Waste. Vol. 1 (1) pp. 008-12, July 2015. Sekolah Tinggi Teknologi Nuklir-Badan Tenaga Nuklir Nasional, Yogyakarta.

Kasam, (2011) Analisis Resiko Lingkungan Pada Tempat Pembuangan Akhir (TPA) Sampah (Studi Kasus: TPA Piyungan Bantul). Jurnal Sains dan Teknologi Lingkungan, Vol.3, No 1 jan 2011 Hal. 019-030 Program Studi Teknik Lingkungan-FTSP, Universitas Islam Indonesia, Yogyakarta.

Santoso, Haryo., dan Puji Nugrahaeni., (2015), Penerapan Green Productivity Untuk Peningkatan Produktivitas Dan Kinerja Lingkungan Di Pabrik Gula Sragi. Seminar Nasional IENACO, Program Studi Teknik Industri, Fakultas Teknik, Universitas Diponegoro, Semarang.

Singgih, Moses L. (2012). Green Productivity: Konsep dan Aplikasi. Institut Teknologi Sepuluh Nopember. Surabaya. 
